\title{
Male Phenotype
}

National Cancer Institute

\section{Source}

National Cancer Institute. Male Phenotype. NCI Thesaurus. Code C46112.

An animal who is observed by researcher or clinician to be male, the sex that ordinarily produces sperm. 